\title{
INFLUENCE OF Spartina alterniflora AND TIDE LEVEL ON THE STRUCTURE OF POLYCHAETE ASSOCIATIONS IN AN EURYHALINE SALT MARSH IN CANANÉIA LAGOON ESTUARINE REGION (SE BRAZIL)
}

\author{
Fabiano da Silva Attolini*; Máurea Nicoletti Flynn \& Airton Santo Tararam \\ Instituto Oceanográfico da Universidade de São Paulo \\ *e-mail : attolini@usp.br \\ (Caixa. Postal 66149, CEP 05315-970, São Paulo, SP, Brasil)
}

- Abstract: Polychaete species composition, abundance and seasonal variation were analyzed in relation to Spartina alterniflora cover and tide level at Ponta do Arrozal, Cananéia, during $1989 / 1990$. Two intertidal stations were located on the $S$. alterniflora belt, one ca mean high water of neap tides (MHWN) and the other ca mean high water of spring tides (MHWS). Two other stations were established at corresponding tide levels at an adjacent site devoid of vegetation. A total of 17 species were collected. Each station was sampled twice seasonally with a $20 \mathrm{~cm}$ of diameter corer. Capitella capitata, Isolda pulchella, Nereis oligohalina and Lumbrineris sp were the most abundant species. Statistically significant differences between the vegetated and bare sites considered were observed for the number of species, density, diversity and evenness, with their values being higher at the vegetated site. Multivariate analysis showed spatial variations of the fauna according to vegetation cover and tide level. In relation to vegetation cover, polychaetes assemblages were distinguishable mainly by individual species densities of the more common species, since the most abundant species were present at the vegetated and bare sites. In relation to tide level, the faunal densities and number of species at the MHWN station were significantly higher than those at the MHWS station mainly at the bare site.

- Resumo: Analisou-se a composição, abundância e variação sazonal de espécies de poliquetas em relação à cobertura vegetal de Spartina alterniflora e o nível de maré na Ponta do Arrozal, Cananéia, nos anos 1989/1990. Duas estações entremarés foram estabelecidas no cinturão de $S$. alterniflora, uma na linha da média de marés altas de quadratura (LMMQ) e outra, na linha da média de marés altas de sizígia (LMMS). Duas outras estações de coleta foram estabelecidas a níveis de maré correspondentes, em um local adjacente desprovido de vegetação. Cada estação foi amostrada duas vezes à cada estação do ano, com auxílio de um corer de $20 \mathrm{~cm}$ de diâmetro. Foram obtidas 17 espécies, sendo as mais abundantes Capitella capitata, Isolda pulchella, Nereis oligohalina e Lumbrineris sp. Diferenças estatisticamente significativas foram observadas em relação ao número de espécies, densidade, diversidade e equidade, sendo os valores destes índices sempre maiores no local vegetado. A análise multivariada mostrou uma variação espacial da fauna em relação à presença de cobertura vegetal e níveis de maré. Em relação à cobertura vegetal, associaç̋̃es de poliquetas foram distinguiveis principalmente pelas diferentes densidades das espécies mais comuns, já que a maioria destas espécies foram encontradas em ambos os locais. Em relação ao nível de maré, tanto as densidades quanto o número de espécies foram significativamente mais altos no nível LMMQ, principalmente no local desprovido de vegetação.

- Descriptors: Plant cover, Tide level, Intertidal, Polychaeta associations, Spartina alterniflora marsh, Cananéia, Brazil.

- Descritores: cobertura vegetal, níveis de maré, entremarés, associações de Polychaeta, marisma de Spartina alterniflora, Cananéia, Brasil. 


\section{Introduction}

Macrobenthic associations can be highly influenced in terms of composition and speciss densities by structural elements such as plant cover (Lewis \& Stoner, 1983; Lana \& Guiss, 1991). This faunal variability is normally attributed to the effect of density and size of macrophyta on physical characteristics such as current speed and sediment stability (Peterson et al, 1984), modification in biological interactions such as predation (Heck \& Thoman, 1981; Flynn, 1993) and biology of individual species with respect to suitability of macrophyta as food and living space (Schneider \& Mann, 1991). But a consistent ecological generalization concerning the faunal regulation in marine vegetated habitats has not yet arisen in the literature making it difficult to predict the composition, abundance and dynamics of softsubstrate communities at unexamined sites. This is primarily caused by the great variability in patterns and processes operating in marine soft-substrate habitats (Kneib, 1984; Edgar et al, 1994).

In Cananeia region, as in any other monoculture marsh, Spartina alterniflora grows in the intertidal zone and although there is a continuous gradient between the mangrove and the sea, two sub-zones, a lower and upper marsh, can be defined in terms of topography and its consequent tidal flooding being the demarcation line ca MHW (mean high water) (Mckee \& Patrick, 1988). Although the potential for tidal events to influence many aspects of salt marsh species is readily apparent, there are few investigations of tidal effects on the species distribution (Adam, 1993). A coherent model of softsubstrate community organization can only be developed if questions about the relative importance of various physical and biological factors affecting the distribution of organisms along tidally induced gradients were answered. For that, description of cryptic intertidal distribution patterns of softsubstrate infaunal organisms, scarce in the literature, must be attended to permit an understanding of the community dynamics. Concerning specifically Brazilians subtropical salt-marshes few studies have been published (Capitoli et al., 1978; Tararam \& Wakabara, 1987; Takeda, 1988; Lana \& Guiss, 1991; Flynn et al., 1996).

In this paper we compare the structural and temporal variability of polychaete associations at a vegetated and nearby unvegetated sites at two different tide levels. Species composition and abundance are analyzed in relation to important factors in the distribution of salt marsh invertebrates such as substrate, plant cover and tide level.

\section{Materials and methods}

The research was conducted at Ponta do Arrozal $\left(25^{\circ} 02^{\prime} \mathrm{S}-47^{\circ} 56^{\prime} \mathrm{W}\right)$, in the euryhaline sector of Cananéia lagoon estuarine region (Fig. 1), where a discontinuous monospecific stand of Spartina alterniflora ca $25 \mathrm{~m}$ wide and $1100 \mathrm{~m}$ long occurs. Local tides are characterized by diurnal inequalities and an almost semidiurnal pattern in maximal tidal amplitudes, ca $1.8 \mathrm{~m}$ (Mesquita \& Harari, 1988). Salinity ranges from $28 \mathrm{ppm}$ to $31 \mathrm{ppm}$ and sea water temperature from $20^{\circ} \mathrm{C}$ in winter to $32^{\circ} \mathrm{C}$ in summer. A complete description and characterization of the system is given by Schaeffer-Novelli et al, (1990).

Two intertidal stations were located on the $S$. alterniflora belt, one at ca mean high water of neap tides (MHWN) and the other ca mean high water of spring tides (MHWS). Two others intertidal stations were established at corresponding tide levels at an adjacent site devoid of vegetation.

Faunal and environmental samples were taken once each season in August 1989 (winter), November 1989 (spring), February 1990 (summer) and May 1990 (autumn). Surface water temperature was determined by a thermometer, salinity by a hand refractometer and dissolved oxygen was analyzed according to Strickland and Parsons (1968). Sediment samples were analyzed for sand and siltclay percentage (Suguio, 1973) and for organic matter by the $\mathrm{H}_{2} \mathrm{O}_{2}$ digestion method. The total biomass of $S$. alterniflora was measured for each sample as wet weight after a drying period of 24 hours in the shade.

Faunal samples consisted of 2 replicates for each sampling station taken by a corer with $20 \mathrm{~cm}$ of internal diameter buried in $10 \mathrm{~cm}$ of the sediment, collected at low tide. Sediment and rhizome mat samples were sieved through $1 \mathrm{~mm}$ and $0.5 \mathrm{~mm}$ meshes, the organisms were fixed in $10 \%$ formalin and then preserved in $70 \%$ ethanol. All polychaetes specimens were identified at the lowest practical taxonomic level and counted under a dissecting microscope. The number of species (S), total polychaete density $\left(\mathrm{N}^{\circ}\right.$ ind $\left./ 0.06 \mathrm{~m}^{2}\right)$, diversity (Shannon's index $\mathrm{H}^{\prime}$ ) and evenness (Pielou's index $\mathrm{J}$ ) were recorded for each station at each season.

One - way analysis of variance (ANOVA) was used to test for differences in water parameters such as temperature, salinity and dissolved oxygen. Two way analyses of variance were used in order to test for differences in sediment (\% of sand, \% of silt-clay and organic contents), polychaete association $(\mathrm{N}, \mathrm{s}$, $H^{\prime}, J$ ), and plant biomass parameters among habitat types and sampling periods. A 5\% level of confidence was assumed. 


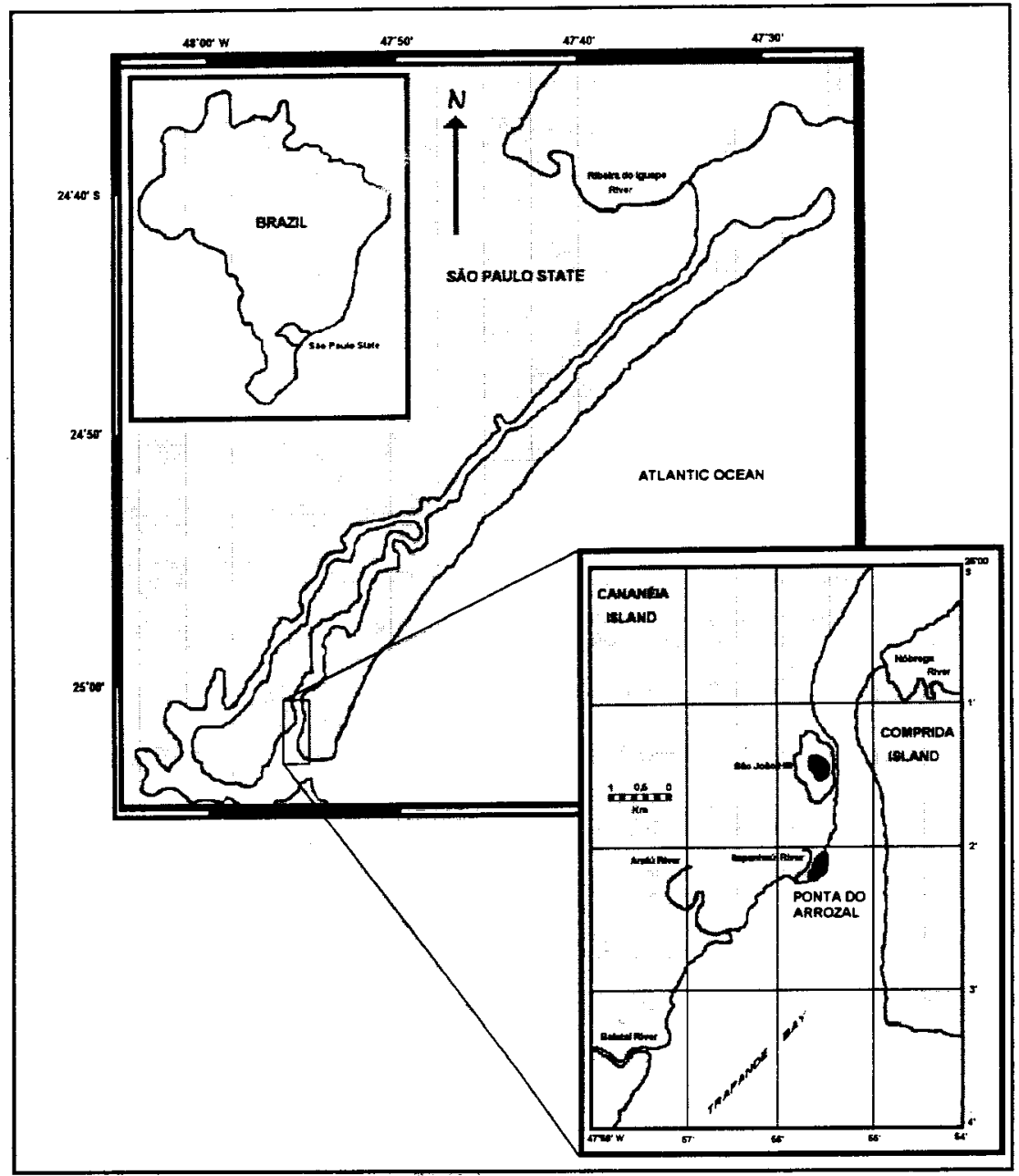

Fig. 1. Location of sampling site in Cananéia lagoon-estuarine region, São Paulo State.

Principal components analysis (Legendre \& Legendre, 1983) was employed in order to reduce the multivariate nature of the data to a few interpretable dimensions. $\log (x+1)$ transformations were applied to reduce the heterogeneity of the raw data. The data matrix included 23 variables (18 faunal parameters and 5 sediment and plant biomass parameters) for each of the 16 observations (4 sampling seasons in 4 different stations). In factorial maps each sample was identified by 2 letters representing seasons: WI - winter, $\mathrm{AU}$ - autumn, SU - summer and SP - spring, followed by L1 or L2 representing, respectively, the tide levels MHWN and MHWS and VEG or BARE for the vegetated and bare sites. Multivariate analysis program was developed by Dr. Jean L. Valentin (Instituto de Estudos do Mar Almirante Paulo Moreira, Arraial do Cabo, Rio de Janeiro, Brazil).

In presenting the results, the term "site" refers to a habitat type, in this case vegetated or unvegetated habitats and the word "station" to samples taken from different tide level within each habitat.

\section{Results}

Temporal variations in temperature, salinity and dissolved oxygen are shown in Figure 2. Table 1 summarizes the variation range of sea water parameters with the results of one-way ANOVA. These parameters reveal a significant temporal variation with salinity lower in summer, probably due to heavy rain fall, temperature higher in summer and dissolved oxygen higher in spring. Sand and silt - clay percentage were found to be statistically indistinguishable among sites or sampling seasons. However, a higher percentage of sand $(100 \%)$ was found at MHWS bare station, and of silt-clay $(6.11 \%)$ at MHWS vegetated station. Organic matter was also statistically indistinguishable at 0.05 significance level when sampling times or stations were considered. The highest percentage were found at MHWS vegetated station $(0.7$ and 3.3 respectively). Plant biomass were higher at the vegetated site, but statistically indistinguishable among sampling times (Table 2). 


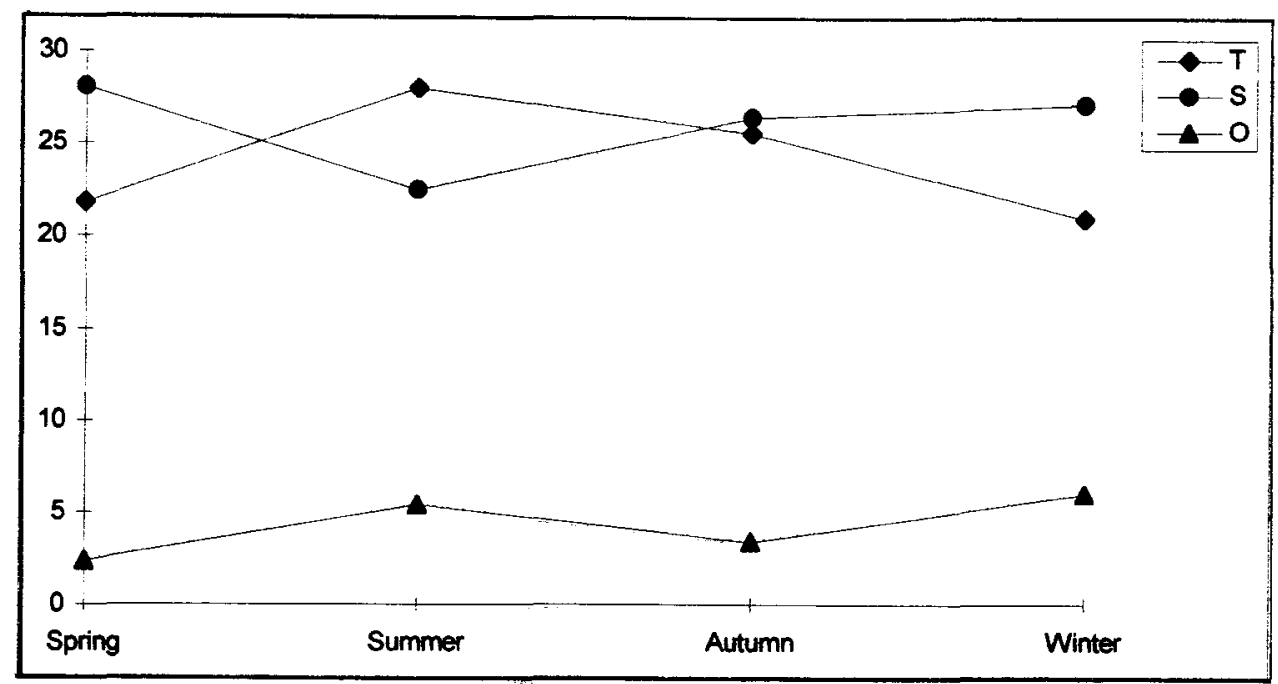

Fig. 2. Temporal variation in temperature $(\mathrm{T})$, salinity $(\mathrm{S})$ and dissolved oxygen $(\mathrm{O})$ of the superficial water.

Table 1. Variation range of superficial water variables and results of one-way ANOVA. $\left(^{*}\right)$ significant at $5 \%$ level of confidence

\begin{tabular}{lcc}
\hline \multicolumn{1}{c}{ Parameters } & Variation Range & P - value \\
\hline Temperature $\left(^{\circ}\right)$ & $22.4-28.1$ & $3.19 \mathrm{E}-7^{*}$ \\
Salinity (ppm) & $20-28$ & $0.00012^{*}$ \\
Dissolved Oxygen (ml-1) & $2.53-6.80$ & $1.15 \mathrm{E}-07^{*}$ \\
\hline
\end{tabular}

A total of 1,900 polychaetes representing 17 species were identified. All 17 species were found on the vegetated site represented by $95.5 \%$ of the total individuals (54\% in the MHWN station and $41.5 \%$ in the MHWS station), being 8 species exclusive of this site. The bare site presented 9 species, none exclusive, accounting for $4.5 \%$ of the total individuals.
The species Capitella capitata, Isolda pulchella, Nereis oligohalina and Lumbrineris sp accounted for $85.8 \%$ of all individuals at both sites. Most of them act as deposit feeders, being the first two tubebuilders and the third discretely motile. Although this species were presented throughout the studied period, marked population fluctuations with no clear seasonal trend were evident (Fig. 3).

Macrofaunal density varied from 1 ind.$/ 0.06 \mathrm{~m}^{2}$ (MHWS bare station in spring) to 546 ind. $/ 0.06 \mathrm{~m}^{2}$ (MHWN vegetated station in winter). Mean densities were statistically higher at the vegetated site. No differences were found among sampling seasons, although, almost invariably, higher densities were found in winter. Highly significant difference in number of species occurred among sites, with higher numbers at the vegetated site. Sampling time were statistically indistinguishable, however higher number of species were found in winter for all stations. Diversity and evenness were statistically distinguishable only among stations, with higher values at the vegetated site (Table 3).

Table 2. Variation range of variables and results of two-way ANOVA evaluating effect of sediment parameters and plant biomass $\left(^{*}\right)=$ significant at $5 \%$ level of confidence; $\left({ }^{*}\right)=$ significant at $1 \%$ level of confidence.

\begin{tabular}{lcccccc}
\hline Parameters & Variation Range & & \multicolumn{3}{c}{ p-values } \\
\hline & L1 veg & L2 veg & L1 bare & L2 bare & time & Sites \\
\hline Sand (\%) & $99.63-99.98$ & $91.49-99.69$ & $99.55-99.9$ & $90.53-100$ & 0.07 & 2.01 \\
Silt - Clay (\%) & $0.02-0.37$ & $0.31-6.11$ & $0.1-0.41$ & $0-0.66$ & 0.33 & 1.06 \\
Organic matter (\%) & 0 & $0.1-0.7$ & 0 & $0-0.3$ & 0.14 & 7.11 \\
Biomass of Spartina (g) & $19.3-59$ & $92-232.5$ & 0 & 0 & 1.38 & $21.14\left(^{* *}\right)$ \\
Number of species (s) & $7-12$ & $5-10$ & $1-4$ & $1-2$ & 3.62 & $36.48\left(^{*}\right)$ \\
Density (inds/0,06m $)$ & $44-546$ & $13-357$ & $1-27$ & $1-21$ & 1.29 & $3.63\left(^{*}\right)$ \\
Diversity (H') & $0.634-1.751$ & $0.583-1.733$ & $0-1.055$ & $0-0.191$ & 3.36 & $12.11\left(^{* *}\right)$ \\
Evenness (J) & $0.326-0.797$ & $0.362-0.89$ & $1.7 \mathrm{E}+38-0.96$ & $1.7 \mathrm{E}+38-0.276$ & 1.50 & $4\left({ }^{*}\right)$ \\
\hline
\end{tabular}



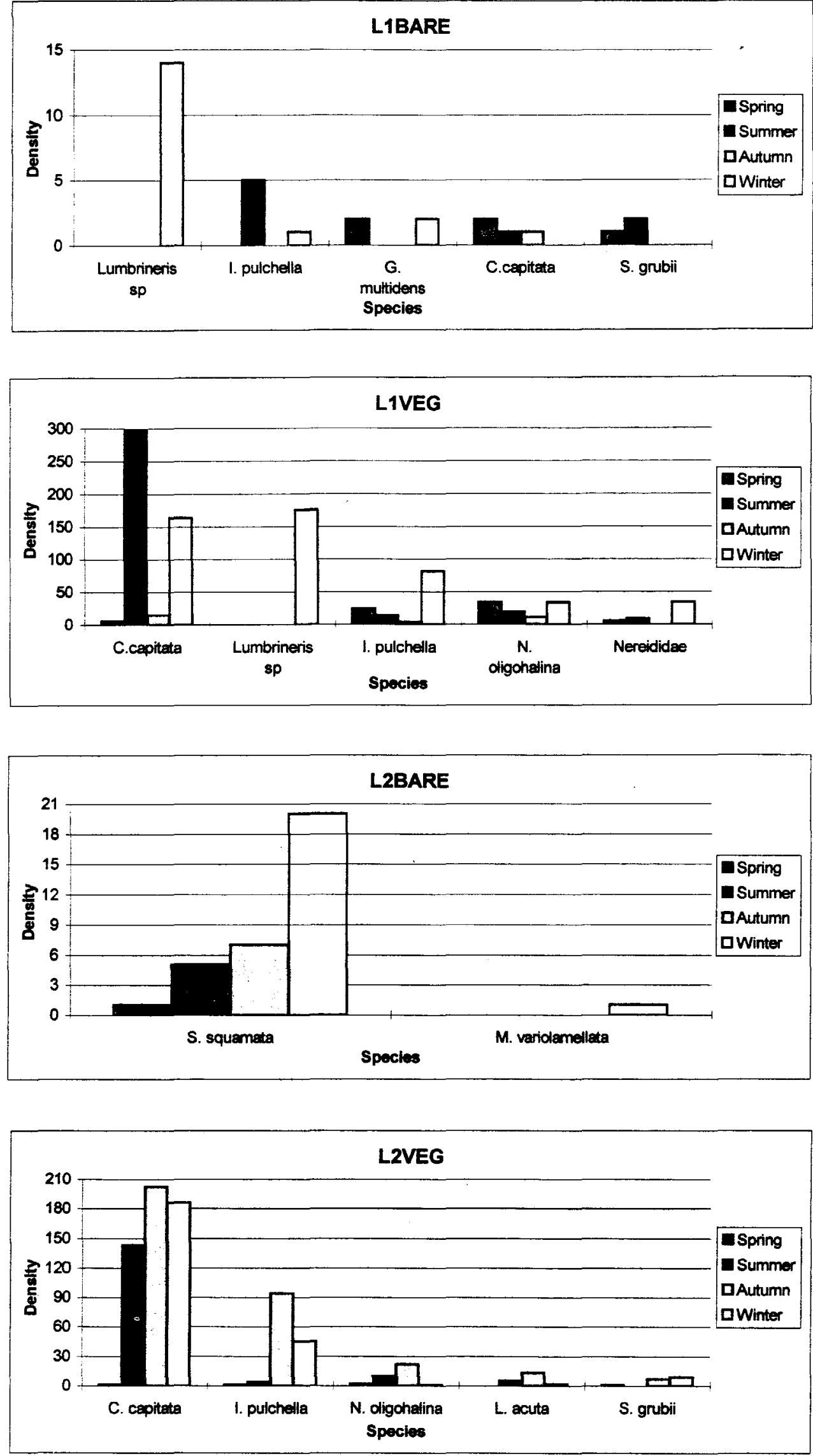

Fig. 3 - Distribution and density of dominant species per $0.06 \mathrm{~m}^{2}$ at each sampling site. 
Table 3. Species number (S), density (D), diversity $\left(\mathrm{H}^{\prime}\right)$ and evenness $\left(\mathrm{J}^{\prime}\right)$ at each sampling site and season.

\begin{tabular}{|c|c|c|c|c|c|c|c|c|c|}
\hline & $\mathrm{S}$ & D & $\mathrm{H}^{\prime}$ & $\mathbf{J}^{\prime}$ & & $\mathrm{S}$ & D & $\mathrm{H}^{\prime}$ & $\mathrm{J}^{\prime}$ \\
\hline \multicolumn{5}{|c|}{ Llveg } & \multicolumn{5}{|c|}{ L2veg } \\
\hline Spring & 9 & 88 & 1.672 & 0.761 & Spring & 2 & 27 & 0.158 & 0.229 \\
\hline Summer & 7 & 348 & 0.634 & 0.326 & Summer & 5 & 166 & 0.583 & 0.362 \\
\hline Autumn & 9 & 44 & 1.751 & 0.797 & Autumn & 10 & 357 & 1.266 & 0.550 \\
\hline Winter & 12 & 546 & 1.738 & 0.699 & Winter & 9 & 253 & 0.883 & 0.402 \\
\hline Spring & 3 & $\begin{array}{c}\text { L1 bare } \\
5\end{array}$ & 1.055 & 0.960 & Spring & 0 & $\begin{array}{c}\mathrm{L} 2 \text { bare } \\
0\end{array}$ & 0 & $\begin{array}{c}1.70 \mathrm{E}+3 \\
8\end{array}$ \\
\hline Summer & 7 & 13 & 1.733 & 0.890 & Summer & 1 & 5 & 0 & $\begin{array}{c}1.70 \mathrm{E}+3 \\
8\end{array}$ \\
\hline Autumn & 1 & 1 & 0 & $1.70 \mathrm{E}+38$ & Autumn & 1 & 7 & 0 & $\begin{array}{c}1.70 \mathrm{E}+3 \\
8\end{array}$ \\
\hline Winter & 4 & 18 & 0.761 & 0.549 & Winter & 2 & 21 & 0.191 & 0.276 \\
\hline
\end{tabular}

Samples, parameters and species points were projected on a similar scale in the factorial space in order to clarify affinities of species to sample and environmental factors. The first component accounted for $33.2 \%$ of the total variance and represented vegetated site, with positive co-ordinates, characterized by the presence of $S$. alterniflora, high faunal abundance and high number of species, opposed to bare site, with negative co-ordinates, characterized by low faunal richness and abundance. The second component ( $18.2 \%$ of total variance) was associated with sediment parameters distinguishing stations with a higher percentage of sand, both from the bare site and the MHWN vegetated station, from the MHWS vegetated station with higher percentage of silt and organic matter (Fig. 4a).

Although most species were present at both the vegetated stations, a distinct pattern of abundance was evident. Species of the upper right quadrant were associated with the MHWN vegetated station, being Lumbrinereis hebes, Perinereis vancaurica, Perinereis sp. and Diopatra sp. exclusive of this station, while Glycinde multidens, Neanthes succinea, Sigambra grubii, Lumbrineridae and Nereididae were more common at this station. Species of the lower right quadrant were associated with the MHWS vegetated station, being Perinereis ponteni exclusive, while Glycera americana, Isolda pulchella, Nereis oligohalina, Capitella capitata and Laeonereis acuta more abundant at this station. Scolelepis squamata, at the lower left quadrant, was the only species more abundant at the bare site and exclusive of the MHWS stations (Fig. 4b).

\section{Discussion}

Evidence is presented that both tidal level and the presence of vegetation play an important role in structuring the macrobenthic polychaetes associations at a sub-tropical tidal flat.

When considering the vegetated in relation to the bare site, the differences in number of species and mean densities are remarkable. The presence of vegetation allows the establishment of a much richer association since the species Diopatra sp., Glycera americana, Laeonereis acuta, Lumbrinereis hebes, Perinereis sp., Perinereis vancaurica, Sigambra grubii, Nereididae and Phyllodocidae absent in unvegetated areas and Capitella capitata, Isolda pulchella and Nereis oligohalina rare in nearby bare sediment showed a strong association with $S$. alterniflora biomass, in agreement with Rader (1984) who noticed the existence of small-scaled aggregation of infaunal organisms with the stems of saltmarsh vegetation.

The high densities of polychaetes at the vegetated sites was probably related to the shelter or food provided by the plant structure since although plant cover can change the sedimentological environment in marine habitats, no statistical difference was evident between vegetated and bare sites. Another probably important factor is the sediment oxygenation propitiated by the $S$. alterniflora's roots and rhizomes mats which enhance infaunal colonization (Teal \& Wieser, 1966). 

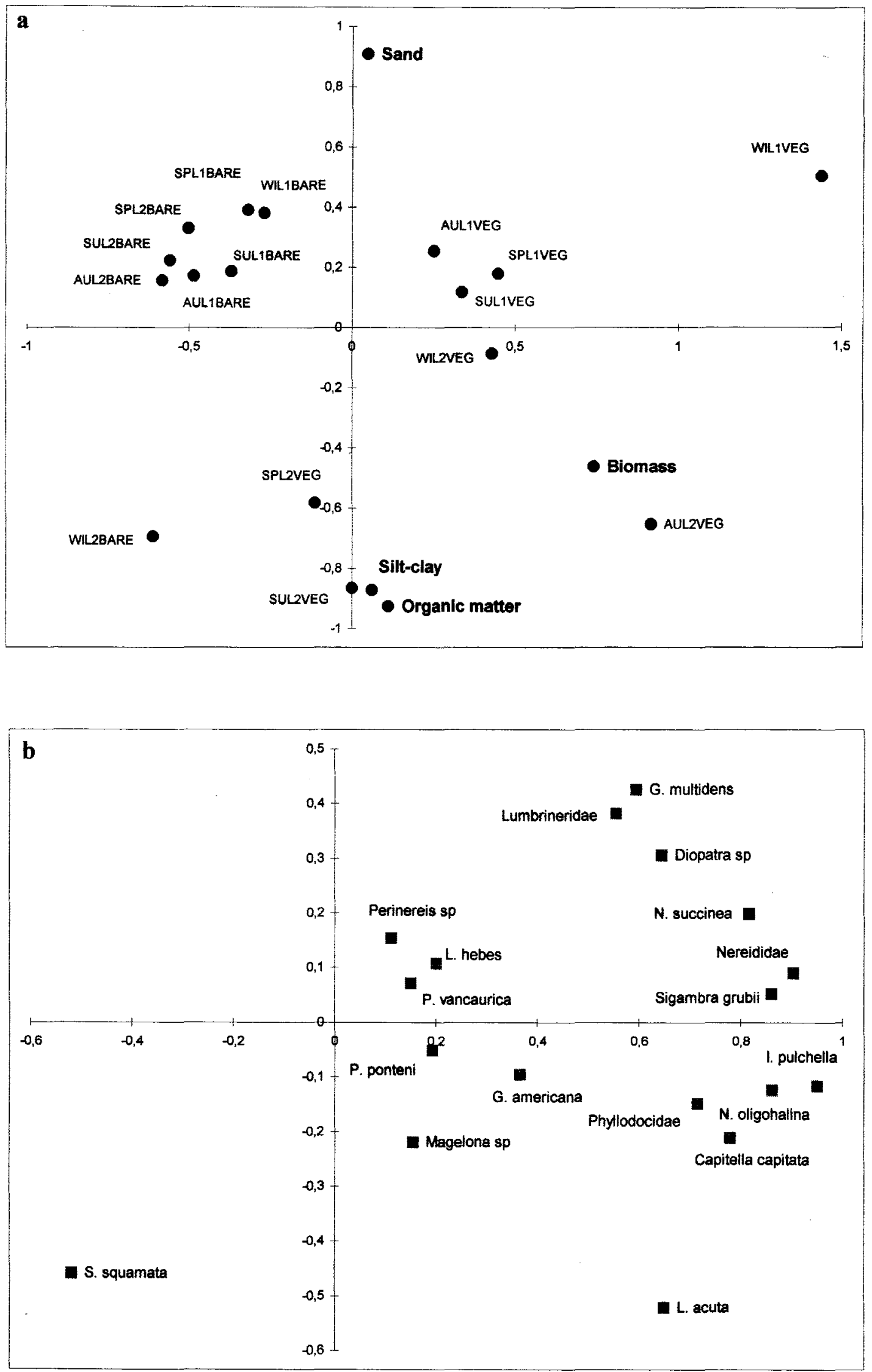

Fig. 4. Principal component analysis of : a) sampling seasons, sediment and biomass parameters at each sampling site; b) species at each sampling site. 
Contrasting with the vegetated stations, the number of species and macrofaunal densities were remarkably low at the bare stations. Species composition was characterized by few polychaete species, none exclusive of unvegetated sediment, in far lower densities since the species closely associated to the root-rhizome mat were excluded due to the absence of the adequate substrata for attachment, sheltering and feeding, besides the reduced detrital input caused by the absence of a plant cover that is of the utmost importance for the deposit feeders (Lana \& Guiss, 1991), the predominant trophic type represented in this study. This fact suggests an efficient utilization of indigenous detrital energy in tidal marshes (Subramanyan et al, 1976).

In relation to tide levels in bare stations there was a reduction in number of species from the MHWN station, with 7 species, to the MHWS station with 2 species. In the first tide level species common to the vegetated site were observed in lower densities such as Capitella capitata, Glycinde multidens, Isolda pulchella, Neanthes succinea, Nereis oligohalina, Sigambra grubii and Lumbrineridae, related to frequently-flooded zone. In the MHWS station just Scolelepis squamata and Magelona variolamellata were present.

At the vegetated stations, although most species were present at both tide level, distinct patterns of abundance were evident. As observed by Flynn (1993), some polychaetes as Isolda pulchella, Nereis oligohalina and Capitella capitata were more abundant at the MHWS tide level, probably due to the higher content of organic matter and detritus (Pardal et al., 1993; Sarda et al., 1995). Lewis \& Stoner (1983) observed that capitelid polychaetes aggregated under Thalassia plants where the concentration of detritus material can be higher. This species is also known to be resistant to pollution but not to wide salinity ranges (Amaral, 1979). Flynn et al. (1996) showed that $N$. oligohalina, I. pulchella and $C$. capitata preferred areas with high vegetal biomass derived from densely aggregated $S$. alterniflora stands. The difference between the associations of the two tide level considered is far more pronounced at the bare site since the plant cover provides a higher habitat complexity, stability of the sediment, protection from predation and food abundance besides promoting seawater retention (Young et al., 1976; Stoner, 1980; Heck \& Thoman, 1981; Orth et al., 1984).

Although there were fluctuations in faunal numbers of species and densities no temporal differences were statistically evident as already reported by Flynn (1993) in relation to polychaetes species. It seems that the dominant infaunal polychaetes don't present a population dynamics which impose statistically distinguishable variations in densities. This is in accordance with Levinton (1972) predictions that state that detritivorous communities are more stable in time, suggesting that a relatively stable population of polychaetes persisted throughout the year. The observed summer and winter peaks were caused by an increase in the population size of Lumbrineris sp. and Capitella capitata in the MHWN vegetated station, Isolda pulchella and Lumbrineris sp. in the MHWN bare station. Scolelepis squamata was responsible for the winter peak in the MHWS bare station and Capitella capitata for the autumn peak in the MHWS vegetated station. Rapid population increases are explained in terms of the settlement of planktonic larvae and rapid growth rates of brooding invertebrates (Edgar \& Moore, 1986). It is possible that the low spring densities might be due to grazing by several species of fish which forage on infauna and present higher densities in spring (Tararam \& Wakabara, 1987).

As pointed out by Santos \& Simon (1974) for a subtropical estuarine environment at Lassing Park, Florida, vegetated areas and areas devoided of vegetation support assemblages of infaunal polychaetes distinguishable mainly by individual species densities. Our analysis indicates that for Cananeila estuary the same is true since the most abundant species were present at both the vegetated and bare sites, but a distinct pattern of abundance was evident with individual populations in higher numbers at the vegetated stations, as well as diversity and eveness values. In relation to tide level, the faunal densities at the MHWN stations were significantly higher than those at the MHWS stations. This may partly be due to the MHWN stations proximity of the estuary in addition to greater tidal flooding, providing easier accessibility to estuarine species and greater abundance of organic detritus (Subramanyam et al., 1976).

\section{References}

Adam, P. 1993. Saltmarsh ecology. Cambridge, Cambridge University Press. 445p.

Amaral, A. C. Z. 1979. Ecologia e contribuição dos anelídeos poliquetos para a biomassa bêntica da zona das marés, no litoral norte do Estado de São Paulo. Bolm Inst. oceanogr., S Paulo, 28(1):1-52. 
Capitoli, R. R.; Bemvenuti, C. E. \& Gianuca, N. M. 1978. Estudos de ecologia bentônica na região estuarial da Lagoa dos Patos. I - As comunidades bentônicas. Atlântica, 3:5-22.

Edgar, G. J. \& Moore, P. G. 1986. Macro-algae as habitat for motile macrofauna. Monogr. biol., 4:255-277.

Edgar, G. J.; Shaw, C.; Watson, G.F. \& Hammond, L.S. 1994. Comparisons of species richness, size-structure and production of benthos in vegetated and unvegetated habitats in Western Port, Victoria. J. expl mar. Biol. Ecol., 176:201226.

Flynn, M. N. 1993. Aspectos ecológicos das associações de espécies e avaliação do efeito da predação sobre a estrutura da macrofauna bentônica de bancos de Spartina (Cananéia, SP, Brasil). Tese de doutorado. Universidade de São Paulo, Instituto Oceanográfico. 84p.

Flynn, M. N.;Tararam, A. S. \& Wakabara, Y. 1996. Effects of habitat complexity on the structure of macrobenthic association in a Spartina alterniflora marsh. Rev. bras. oceanogr., 44(1):9-21.

Heck Jr., K. L. \& Thoman, T. A. 1981. Experiments on predator-prey interaction in vegetated aquatic habitats. J. expl mar. Biol. Ecol., 53:125-134.

Kneib, R.T. 1984. Patterns of invertebrate distribution and abundance in the intertidal saltmarsh : causes and questions. Estuaries, $7: 392-412$.

Lana, P. C. \& Guiss, C. 1991. Influence of Spartina alterniflora on the structure and temporal variability of macrobenthic associations in a tidal flat of Paranaguá Bay (Southeastern Brazil). Mar. Ecol. Prog. Ser., 73:231-244.

Legendre, L. \& Legendre, P. 1983. Numerical ecology. Development in environmental modelling, 3. Amsterdam, Elsevier Scientific Publishing Company. 419p.

Levinton, J. S. 1972. Stability and trophic structure in deposit-feeding and suspension-feeding communities. Am. Nat., 106:472-486.
Lewis, F. G. \& Stoner, A. W. 1983. Distribution of macrofauna within seagrass beds: an explanation for patterns of abundance. Bull. mar. Sci., 33:296-304.

Mckee, K. L. \& Patrick, W. H. 1988. The relationship of smooth cordgrass (Spartina alterniflora) to tidal datums: a review. Estuaries, 11(3):143-151

Mesquita, A. R. \& Harari, J. 1988. Tábuas das marés de Ubatuba e Cananéia para os anos de 1988 e 1989. Relat. int. Inst. oceanogr. Univ. S Paulo, 24:1-20.

Orth, R. J.; Heck Jr., K. L. \& Weinstein, M. P. 1984. Faunal relationships in seagrass and marsh ecosystems. Estuaries, 7:273-274.

Pardal, M. A.; Marques, J. -C. \& Bellan, G. 1993. Spatial distribution and seasonal variation of subtidal polychaete populations in the Mondego estuary (western Portugal). Cah. Biol. mar., $34: 497-512$.

Peterson, C. H.; Summerson, H. C. \& Duncan, P. B. 1984. The influence of seagrass cover on population structure and individual growth rate of a suspension-feeding bivalve, Mercenaria mercenaria. J. mar. Res., 42:123-138.

Rader, D. N. 1984. Salt-marsh benthic invertebrates: small-scale patterns of distribution and abundance. Estuaries, 7:123-138.

Santos, S. L. \& Simon, J. L. 1974. Distribution and abundance of the polychaetous annelids in a South Florida estuary. Bull. mar. Sci., 24(3):669-689.

Sarda, R; Foreman, K. \& Valiela, I. 1995. Macroinfauna of a southern New England salt marsh: seasonal dynamics and production. Mar. Biol., 121(3):431-445.

Schaeffer-Novelli, Y.; Mesquita, H. S. L. \& CintrónMolero, G. 1990. The Cananéia lagoon estuarine system, Såo Paulo, Brazil. Estuaries, 13:193-203.

Schneider, F. I. \& Mann, K. H. 1991. Species specific relationship of invertebrates to vegetation in a seagrass bed. I. Correlational studies. J. expl mar. Biol. Ecol., 145:101-117. 
Stoner, A. W. 1980 . The role of seagrass biomass in the organization of benthic macrofaunal assemblages. Bull. mar. Sci., 30:537-551.

Strickland, J. D. \& Parsons, T. R. 1968. A practical handbook of seawater analysis. J. Fish. Res. Bd Can., 197:1-311.

Subrahmanyan , C. B.; Kruczynski, L. \& Drake, S. H. 1976. Studies on the animal communities in two North Florida saltmarshes. Part II. Macroinvertebrate communities. Bull. mar. Sci., 26(2):172-195.

Suguio, K. 1973. Introdução a sedimentologia. São Paulo, Edgard Blucher/EDUSP. 312p.

Takeda, A. M. 1988. Estruturas de associações macrobênticas da Spartina alterniflora Loiseleur, 1807 no complexo estuarino-lagunar de Cananéia. Tese de doutorado. Universidade de São Paulo, Instituto Oceanográfico. 70p.

Tararam, A. S. \& Wakabara, Y. 1987. Benthic fauna living on Spartina alterniflora of Cananéia estuarine region $\left(25^{\circ} 02^{\prime} \mathrm{S}-47^{\circ} 56^{\prime} \mathrm{W}\right)$. Bolm Inst. oceanogr., S Paulo, 35(2):103-113.

Teal, J. M. \& Wieser, W. 1966. The distribution and ecology of nematodes in a Georgia salt-marsh. Limnol. Oceanogr., 11:217-222.

Young, D. K.; Buzas, M. A. \& Young, M. W. 1976. Species densities of macrobenthos associated with seagrass. A field experimental study of predation. J. mar. Res., 34:577-592.

(Manuscript received 27 February 1997; revised 02 O2 July 1997, accepted 29 October 1997) 